\title{
Accounting professional applied talents training mode research in colleges and universities
}

\author{
Xiumei LI \\ Weifang University of Science and Technology \\ Shouguang,Weifang,Shandong, 262700 China
}

\begin{abstract}
The accounting professional applied talents training mode is related to the quality of the cultivation of applied talents. Deeply understanding and grasping the characteristics and requirements of applied talents training mode of the accounting major in the new period, is of great significance to cultivate high quality accounting applied talents that can meet the requirements for the development of the socialist market economy, internationalization. As the economy develops, the accounting becomes more important. Along with the further development of our market economy construction, society put forward higher and higher requirements for accounting practitioners. Applied talents training mode in the major of accounting in colleges and universities is an important problem related to the quality of accounting applied talents training.
\end{abstract}

Keywords- accounting in colleges and universities; applied talents; training mode

\section{INTRODUCTION}

Accounting is one of the top popular majors in colleges and universities in our country and accounting major applied talents are in great demand in society. Since the enrollment expansion of colleges and universities, a large number of accounting major graduates enter the society, however in the situation that market supply and demand of the applied talents are both flourishing, there comes the dilemma that the total of accounting professional graduates is surplus but the structure is lacking. The main reason is that applicationoriented accounting talents cultivated by accounting major in colleges and universities of applied talents training mode cannot meet the needs of social development of applied talents, therefore, the reform of accounting major of applied talents training mode in colleges and universities is imperative.

\section{A. Ability to construct knowledge}

Transformation and the rapid development of economy in China in the 21 st century promote the transformation of enterprise development mode, and put forward higher requests for accounting applied talents of enterprise, and determine the change of applied talents training mode in the major of accounting in colleges and universities. Relative to other social sciences, accounting discipline has stronger social practicality, and students need to have stronger accounting practical operating ability, which can meet the social demand for high-level application-oriented applied accounting; The rapid development of modern society makes the enterprise's economic, legal and marketable environment change every minute, the uncertainty of enterprise management heightened, brought manifold impact to enterprise accounting, while accounting applied talents in colleges and universities is the fixed school education, and limited study time determines that the students may not master all the knowledge during the period of college study, and the knowledge ability of the students, will not happen overnight.

\section{B. Curriculum system constructing}

The setting of accounting professional curriculum system in colleges and universities should follow the principles such as combining and paying equal attention to theory and practice, enriching moderate contents, using flexible forms. Combining the theory and practice means that the course system should include two parts: the theory curriculum system and practice curriculum system, and pay attention to the combination of the two; Paying equal attention means that the curriculum system setting should embody the combination of general education and professional education, pay attention to the discipline overlapping and meet applied talents quality requirements of thick foundation, wide caliber; Enriching moderate content emphasizes that the curriculum system setting should consider moderately factors such as the student's ability to bear, individual differences, and then streamline and integrate required course, and increase the elective course, to cultivate high quality applied talents; Flexible forms mainly refers that the practical curriculum should value both hand practice and computer simulation, both cross in-class practice and the extracurricular practice, and campus practice combined with outside school practice.

\section{Teaching methods, construction of system and evaluation system}

For accounting applied talent cultivation is the main staff of the university teachers, and the training object is students, therefore, to realize the goal of accounting applied talents training will need to emphasize two-way interactive process between the educators and the educated. On the teaching method we should pay attention to the teacher's leading position and student's main body status. Teaching should take the double teachers(i.e., the school teachers and extramural school teachers), double classes (i.e., the classroom teaching and outside class) as the foundation, implement heuristic, exploratory teaching with multimedia teaching, network teaching, bilingual teaching as the method, 
in order to realize the teachers' creative teaching and students' creative learning.

\section{THE FLAWS IN CULTIVATING THE ACCOUNTING MAJOR APPLIED TALENTS IN COLLEGES AND UNIVERSITIES}

At present, there are many problems in the accounting professional personnel training, to a certain extent, which restricted the university related specialized scale expanding, and hindered the development of accounting major applied talents in colleges and universities.

\section{A. Goals do not agree with social needs.}

The position in accounting major applied talents training target is too high, and only pay attention to teaching students theoretical knowledge, but ignore teaching students how to apply these knowledge. The result is that accounting major graduates had failed to meet the requirement of the society, and the most obvious and direct is accounting major graduates' employments are difficult, and employ persons complain graduates' practical ability is poor, and they must pass through a period of training to entrusts with an important task. Graduates actual hands-on ability is poor, and there is no doubt that it is related to the practice teaching they accepted in school.

The system of the curriculum is not perfect enough. Accounting teaching focuses on teaching the accounting professional knowledge, and often done through setting up a series of accounting course teaching, pay attention to the development of theory of knowledge in the curriculum, ignore the cultivation of the practical ability and the practice class is less, and in many cases become a mere formality, and fragmented among different subjects, ignored the relationship between each other, including the number of courses, teaching content, etc. Curriculum arrangement is not reasonable, virtually edging out the practice time, and always in a hurry formal, practice effect is not good.

The teaching method and means is too old. Accounting teaching mainly uses the blackboard writing teaching method, which uses the traditional approach of the teacher write down, students take notes or teacher speak, students listen to accounting teaching, seriously affected the students' computer operation ability, in particular, which were not adapted to the popularization of accounting computerization. Classroom teaching in the organization of the content is as usual accounting regulations, accounting theory teaching primarily, by practice, combined with the case less; Or it focus on the interpretation of accounting theory, after the theory then focus on accounting practice teaching, which artificially dissever the unity of theory and practice of accounting.

The teachers' troop practice ability is not enough. A theoretical knowledge and practice of literacy of double teachers' team is the precondition of accounting major applied talents. Without "double type" teachers, we won't produce outstanding technology applied talents of practical operation ability. And the actual situation is: many teachers directly mounted the platform after graduation, and they lack practical exercises, so they often can't combine teaching and practice very well. Therefore, accounting major should focus on cultivating a "double type" teachers' team.

\section{COLLEGE ACCOUNTING MAJOR APPLIED TALENTS TRAINING MODE REFORM STRATEGY}

\section{A. Strengthen the applicability}

Accounting is an applied economic discipline. Accounting education is to serve economic development. With the development of market economy and the speeding up of economic globalization, the application range of the accounting has become increasingly widespread, the practicability of accounting professional and technical is growing, and professional skill requirements for accounting personnel should possess is also more and more high. Accounting applied talents are specialized personnel who have a certain professional ability and comprehensive quality on the basis of the generalist know-how. The training target of accounting applied talents is to train senior applied special applied talents who adapt to the 21 st century market economy development needs, on top of professional basic theory and practical skills.

\section{B. Promptness}

The accounting specialty is one of the traditional, but it as an important part of economic management, and plays an extremely important role in the process in the modern economic development, and has obvious times. Internationalization of accounting development, as the international general commercial language, accounting internationalization is the trend of its development, the accounting professional education to face the world, it must adapt to the globalization, the international competitive ability of the economy class applied talents, therefore, to timely adjust major setting, curriculum structure, to adapt to the development trend of economic globalization of education idea, teaching content reform, strengthen the English teaching, gradually increase the proportion of bilingual teaching, trains the student to have the international vision and international communication ability.

\section{Reflect innovation}

Innovation is the core competitive edge of the applied talents. As the applied talents in the 21 st century knowledge economy era, they must have the innovation spirit and innovation ability, to make their own work conform, creative, and adapt to the quickly changing social development. Therefore, accounting education pay more and more attention to the innovative education, and emphasis on training students to help students set up the concept of freestanding self-improvement, spur students to work hard, struggle, will be conducive to the education reform in colleges and universities. We hope college actively contact with the bank, to reach an agreement as soon as possible to solve the problem of national student loans difficult students, to help poor students to use tomorrow's money to achieve today's college dream. From the economic environment change on the students in colleges and universities the status 
quo of tuition and fees in arrears, and then promote education enterprise vigorous development.

\section{Regulate the behavior of tuition waiver}

In order to regulate the behavior of tuition, avoid a certain person in charge, we must set up leading group for tuition waiver review, and group members are made up of the bursar's office, try and punish division, office, enrollment, graduate student, student affairs office, head of the unit. According to the ministry of education about the difficulties students tuition, accommodation can be according to actual circumstances, the provisions of the relief, relief team focused review meeting difficulties students regularly breaks, and submitted to the principal for examination and approval; For those who really because of family life difficult can't pay the tuition of students be reduced or exempted in accordance with the difference between different conditions.

\section{ACCOUNTING APPLIED TALENTS CULTIVATION MODEL OF INNOVATION}

\section{A. Infusion and skills training and knowledge}

Knowledge and skills is one aspect of the quality of accounting education connotation. Social skills of accounting personnel demand is higher and higher, business skills of accounting graduates directly affect their employment. In order to adapt to the development of market economy and the challenge of economic globalization, accounting teaching should be about this target that enhance the students' practical operation and combine knowledge and skills, and take the accounting practice as one of the important content of teaching, and configure the corresponding proportion in the process of teaching theory of speaking lesson to let the student to carry on the business accounting simulated operation.

\section{B. Paying equal attention to professional education and moral education}

Accounting personnel is the important vindicator of accounting order and the order of market economy, and the accounting professional ethics in a degree decides the quality of accounting work. The specialty of the accounting profession, determine that accounting personnel should possess higher professional ethics accomplishment. Currently, the problem of discredit in society is quite common, fraud, depend on tax evasion, the accounting information distortion has become the focus of attention in the world, the good faith crisis has become a serious social problem. College accounting major students is an important reserve forces training in accounting industry in our country, their professional moral level and the overall quality of the contingent of accounting of our country has a significant impact.

\section{The school teaching and accounting practice}

In accounting teaching combining theory and practice is an important principle in accounting discipline teaching reform and the basic goal. Strengthening applied accounting practice is the requirement of social development. In the current employment situation, any professional education should regard applied talents market as the guidance, and reflect society's current and future needs. The combination of theory and practice in teaching should optimize the practice teaching content system, to enhance professional training pertinence and effectiveness, and improve the overall effect of the practice teaching.

\section{Learning guidance and vocational guidance}

Accounting professional career goal is clear, and professional guidance is strong. Especially in the current, under the new situation when we take the employment as the guidance, and promote the teaching reform of higher education, the cultivation of accounting major students should adhere to the "equal emphasis on" learning guidance and vocational guidance mode, to cultivate practical applied talents with as well as knowledge and practical skills. Study guides should pay attention to the development of accounting the latest knowledge and skills, guides the student to set up the idea of lifelong learning, pay attention to study habits, learning methods, learning ability cultivation; At the same time according to the post vocational ability and the comprehensive quality of the combination of applied talents training target, we establish a career as the standard, to the cultivation of the market and social needs as the guidance mechanism.

\section{E. Degree certificate and professional qualification certificate}

Accounting practitioner's qualification certificate system requires that colleges and universities must conform to the trend of the development of the industry, and strengthen and guide students to set up the ideas of employment "skill qualification certificate". Colleges and universities in the teaching process should fully consider this factor, and implement the qualifications and professional qualification certificate education mode. In view of this, schools should encourage, support and help the students to get skills certificate, such as grading the abacus certificate, the accounting computerization certificate, accountant card, certificate of computer grade card, etc. Conditional colleges and universities can consider set up a professional training institutions, to carry out the "double certificate" education work.

\section{CONCLUSIONS}

Accounting applied talents as an important part of applied talents team in our country, in the maintenance of market economic order, promoting scientific development, promoting social harmony plays an important role. Cultivation model is the core of the accounting professional applied talents cultivation problems, and colleges and universities in the construction of accounting professional work of cultivating applied talents shoulder the historical mission, and have a long way to go. The construction of accounting professional applied talents training mode is a system process, in this process, colleges and universities should base on accounting applied talents cultivating ability of knowledge structure, construct the curriculum system, pay 
equal attention to theory and practice in the teaching management, scientific and reasonable evaluation system under the guidance of using flexible teaching methods and teaching means, cultivate high quality accounting applied talents who can meet the needs of social development.

\section{ACKNOWLEDGEMENT}

Project: Research on the system of training skilled talents in Colleges and Universities - - Taking computerized accounting specialty of Weifang Institute of science and technology as an example.

\section{References}

[1] Fan Yingying The current accounting major in higher vocational colleges in our country the research sphere of applied talents training mode [J]. Economic research Tribune, 2011 preceding: 255-257.
[2] Ding Hua College accounting major applied talents training mode exploration [J]. Journal of accounting, 2011, 22:29 and 30.

[3] Zhang Haishui. Our country accounting professional applied talents training present situation, problems and future development thinking [J]. Journal of business accounting, 2014,01:12-14.

[4] Liu Ying Applied talents training mode in the major of higher vocational accounting research [J]. Journal of law and society, 2009, 23:299-300.

[5] Nian Suying. College accounting major of applied talents training mode innovation study [J]. Journal of economist, 2008 practices: 108109.

[6] He Junfeng. The accounting professional applied talents training mode innovative thinking [J]. Journal of accounting, friends of the 2006 01:52-53.

[7] Wei Hong Extraction run by the local undergraduate colleges and universities accounting applied talents training mode [J]. Journal of business review, 2012, 13:233-234. 